\title{
BETWEEN REASONABLE AND PROBABLE CAUSE AND MALICE IN THE LAW OF MALICIOUS PROSECUTION: A COMMONWEALTH UPDATE
}

\author{
Chuks Okpaluba
}

LLB LLM PhD

Adjunct Professor of Law

University of Fort Hare

\section{SUMMARY}

Although the requirements of absence of a reasonable and probable cause and malice are two distinct elements in an action for malicious prosecution, they sometimes appear inseparable. An absence of reasonable and probable cause might, in instances, be a clear indication of malice on the part of the prosecution. However, while the absence of reasonable and probable cause is often deduced from the conduct of the prosecutor, judged from the objective standpoint of a reasonable prosecutor possessed of the same information, malice is inferred from the state of mind of the prosecutor as to whether he or she genuinely intended to bring the accused person to justice, or had operated from the angle of vengeance, improper purpose, targeted malice or for any unlawful purpose. Such inference can easily be drawn where the investigating officer and the prosecutor knowingly relied on fabricated information - Minister of Safety and Security $v$ Tyokwana 2015 (1) SACR 597 (SCA). The burden of proof of both elements, though extensively canvassed by the Australian High Court in A v New South Wales (2007) 230 CLR 500 (HCA), has been taken a step further by the New South Wales Court of Appeal in State of NSW v Quirk [2012] NSWCA 216. The Supreme Court of Appeal of South Africa has maintained in Woji v Minister of Police 2014 (1) SACR 409 (SCA) that negligence or gross negligence, short of dolus eventualis, would not suffice in a claim for malicious prosecution. The defendant must have been aware of the wrongfulness of his or her conduct in initiating or continuing the prosecution, but nevertheless continued to act, reckless as to the consequences of his or her conduct.

\section{$1 \quad$ INTRODUCTION}

Along with the requirement that the defendant must have instigated, initiated or continued the prosecution which must have terminated in favour of the plaintiff, the proof of absence of reasonable and probable cause and malice complements the four ingredients that make up the jurisdictional facts for a successful action for malicious prosecution. ${ }^{1}$ The present study sets out to

1 Minister of Safety and Security NO v Schubach [2014] ZASCA 216 par 11; Rudolph $v$ Minister of Safety and Security 2009 (5) SA 94 (SCA) par 16; Minister of Justice and 
analyse the recent case law, relating to the absence of reasonable and probable cause and malice. As much as these two requirements must be proved separately, the case law shows that they sometimes tend to overlap. Thus, when Sir Andrew Leggatt spoke for the Privy Council in Harracksingh $v$ Attorney General of Trinidad and Tobago ${ }^{2}$ that: "charging a person with an offence which the arresting officer knows he has not committed, necessarily involves a lack of honest belief on the part of the officer, and his motive can only have been improper", the Justice was addressing these two interconnected requirements of malicious prosecution. The absence of reasonable and probable cause may be deduced from the conduct of the prosecutor, judged from the objective standpoint of a reasonable prosecutor in that same position, and possessed of the same information. On the other hand, malice can be inferred from the state of mind of the prosecutor as to whether he or she genuinely intended to bring the accused person to justice, or that he or she operated from the angle of vengeance, ill will, improper purpose, targeted malice or other unlawful purpose. Developing further the ten-point guideline laid down by the High Court of Australia in $A v$ New South Wales, ${ }^{3}$ the New South Wales Court of Appeal in State of NSW v Quirk ${ }^{4}$ has gone ahead to strengthen not only contemporary Australian jurisprudence but has also provided the Commonwealth with a universally-accepted criterion with respect to the onus of proof in both absence of reasonable and probable cause and malice in the law of malicious prosecution. For instance, the Privy Council in two recent cases emanating from Trinidad and Tobago and the Cayman Islands, respectively - Trevor Williamson $v$ Attorney General of Trinidad and Tobago ${ }^{5}$ and Crawford Adjusters v Sagicor General Insurance (Cayman) $L t d^{6}$ - has recognised and applied the tests relating to both elements as enunciated by the High Court of Australia in $A v N e w$ South Wales.

Issues concerning the interrelationship between lawfulness of the arrest, the information available to the arresting officer at the time of arrest, as well as the reasonableness of that officer's conduct, continue to rage. Where, for instance, both the arresting officer and the prosecution proceed on false information knowing it to be fabricated, as in the South African Supreme Court of Appeal case of Minister of Safety and Security $v$ Tyokwana, ${ }^{7}$ it is safe to contend that the absence of both reasonable suspicion to arrest and reasonable and probable cause to prosecute could more easily be imputed, and so will malice. The Court of Appeal in England was confronted in Commissioner of Police for the Metropolis $v$ Copeland ${ }^{8}$ as to how the Court would approach the matter of determining the lawfulness of an arrest where the arresting officer had not witnessed the events, where it was alleged that

Constitutional Development v Moleko [2008] 3 All SA 47 (SCA) par 8; and Bayett v Bennett [2012] ZAGPJHC 9 par 167.

[2004] UKPC 3 par 13.

(2007) 230 CLR 500 (HCA).

[2012] NSWCA 216.

[2014] UKPC 29 par 11.

[2014] AC 366 (PC).

2015 (1) SA 597 (SCA).

[2014] EWCA Civ. 1014 (CA). 
the appellant punched a police constable in the face, but had relied on information given to her by another constable. The test for determining this type of matter in the English common law once more came to the fore.

\section{REASONABLE AND PROBABLE CAUSE}

It has already been observed that the third element in establishing a claim for malicious prosecution is that the prosecutor had no honest belief founded on reasonable grounds that the institution of the proceedings was justified. In other words, there must have been the absence of reasonable and probable cause in initiating, instigating, or continuing the prosecution. ${ }^{9}$ It has also been noted that this aspect was thoroughly addressed by the High Court of Australia in $A v$ New South Wales ${ }^{10}$ and, for all practical purposes, a similar view reverberated in respect of the entry of a nolle prosequi in Beckett $v$ New South Wales. ${ }^{11}$ At the risk of repetition, but for the avoidance of doubt, it is the discussion of the "temporal dimension of the tort: proof of the absence of reasonable and probable cause directs attention to the state of affairs at the time the defendant has been alleged to have instigated or maintained the prosecution. Evidence bearing on the existence of reasonable and probable cause is confined to the material available to the defendant at the time the prosecution was commenced or maintained." ${ }^{12}$ In this context, a distinction must be drawn between reasonable suspicion that an offence has been committed so as to justify an arrest, and the existence of reasonable and probable cause to prosecute. For there may be reasonable grounds to arrest, but no reasonable and probable cause to prosecute. But whereas in New South Wales $v$ Zreika, ${ }^{13}$ the evidence available to the arresting officer was not conclusive that the plaintiff was the perpetrator of the shooting in question, as there was no eyewitness account implicating him, the arresting officer ignored the available exculpatory evidence that emerged at the bail hearing, and instead of conducting further investigations, the arresting officer preferred to adopt a closed mind approach and continued the prosecution. Further investigations would conceivably have explained the apparent inconsistencies or, more likely, definitely ruled out the respondent as a suspect. The Court of Appeal of New

9 Biladeau $v$ Ontario 2014 ONCA 848 par 24-31. The recent judgment of the High Court of Trinidad and Tobago in Imran Khan v Attorney General Claim No. CV2012-04559 (17 November 2014) par 63 is a clear illustration of an absence of reasonable and probable cause to prosecute the claimant who alleged that the defendant had fabricated and concocted evidence of the plaintiff having parked his vehicle in a "No Parking", "No Stopping" zone, and for using his vehicle for a purpose for which it was not meant. After an exhaustive review of the evidence, Rampersad $\mathrm{J}$ held that there was a litany of inconsistences and irregularities in the evidence of the defendant, as compared with the "virtually unshaken evidence of the claimant and his witness". The Court came to the conclusion that, based on the preponderance of evidence before it, the prosecuting Assistant Superintendent of Police did not have any reasonable or probable cause to assume that charges should be laid, since his credibility in relation to the grounds for the offences has not stood the test of cross-examination.

10 Supra 520. See the discussion by Okpaluba "Reasonable and Probable Cause in the Law of Malicious Prosecution: A Review of South African and Commonwealth Decisions" 2013 16 Potch ER 241 par 5.

11 (2013) 297 ALR 206 (HCA).

12 Beckett v New South Wales supra par 4; and A v New South Wales supra 520.

13 [2012] NSWCA 37. 
South Wales therefore held that the State's challenge to the finding of the trial judge that the arresting officer had no reasonable grounds for her suspicion that the respondent had committed the offence, must fail. ${ }^{14}$ Neither was the trial judge's finding that, since malice covers any motive other than the desire to bring a criminal to justice, the respondent had established the element of malice required to make out the tort of malicious prosecution. ${ }^{15}$

\section{The lawfulness of the arrest and reasonable and probable cause}

There is a very fine line dividing reasonable suspicion to arrest and reasonable and probable cause to prosecute. Arrest is made at the very beginning of the criminal process and quite often at the commencement of a criminal investigation, whereas the decision to prosecute comes with the conclusion of the investigation into whether an offence has been committed. In Morgan $v$ Attorney General of Trinidad and Tobago, ${ }^{16}$ where the plaintiff claimed wrongful arrest, false imprisonment and malicious prosecution, Kokaram $\mathrm{J}$ explained that an arresting police officer is liable for wrongful arrest or false imprisonment if he or she unlawfully arrests or detains another in circumstances which do not amount to a valid arrest. Such an officer is also liable if he or she makes an arrest but does not comply with the conditions for continued detention, or if the person is detained for an unreasonable time without being brought before a magistrate. ${ }^{17}$ The judge further held that as much as reasonable-and-probable cause is relevant to the tort of false imprisonment as it is to malicious prosecution, in order to justify an arrest, the defendant must show that the arresting officer had reasonable cause to suspect that the person committed an offence, whereas, in malicious prosecution, it is for the claimant to prove that the officer did not have reasonable and probable cause to institute proceedings, and acted maliciously. ${ }^{18}$ What, however, brings the two otherwise divergent principles to apparent conflict is the objective test common to both requirements, which dwells on the information available to the arresting officer, ${ }^{19}$ as well as the prosecutor and the reasonableness of the conduct of

\footnotetext{
New South Wales v Zreika supra par 49 and 56-57.

New South Wales $v$ Zreika supra par 15(iv).

Claim No. CV2013-03924 par 10.

Halsbury's Laws of England (2010) Vol 97 par 545.

Morgan v Attorney General of Trinidad and Tobago supra par 11.

19 In Ramsingh v Attorney General of Trinidad and Tobago [2012] UKPC 16 par 8, where the question was: while it is conceded that the arrest was lawful, but the subsequent detention not, Lord Clarke, delivering the judgment of their Lordships, summarised the relevant principles relating to the law of false imprisonment as follows: (i) the detention of a person is prima facie tortious and an infringement of $s$ 4(a) of the Constitution of Trinidad and Tobago; (ii) it is for the arrestor to justify the arrest; (iii) a police officer may arrest a person if, with reasonable cause, he suspects that the person concerned has committed an arrestable offence; (iv) thus, the officer must subjectively suspect that the person has committed such an offence; ( $v$ ) the officer's belief must have been on reasonable grounds or, as some of the cases put it, there must have been reasonable and probable cause to make the arrest; and (vi) any continued detention after arrest must also be justified by the detaining officer. See also per Lord Denning MR and Diplock LJ Dallison v Caffery [1964] 2 All ER 610617 and 619 respectively; Mauge $v$ Attorney General of Trinidad and Tobago
} 
the respective officers. ${ }^{20}$ It is simply a question of fact as to whether the officer held an honest belief based on a full conviction founded on reasonable grounds that the suspect was probably guilty of the crime imputed. ${ }^{21}$

Although the following has been stated elsewhere, ${ }^{22}$ and reiterated in another context, ${ }^{23}$ it is worth repeating in the present context:

- The question is not whether a police officer believes that he has reason to suspect, "but whether on an objective approach, he in fact has reasonable grounds for his suspicion." ${ }^{24}$ In effect, a reasonable person placed in the position of the officer must be able to conclude that there were indeed reasonable and probable grounds for the arrest. ${ }^{25}$

- What is involved is that the police officer must take account of all the information available to him or her at the time and base the decision to arrest on such information. ${ }^{26}$

- What constitutes reasonable grounds for suspicion had to be judged against what was known, or reasonably capable of being known at the relevant time. ${ }^{27}$

- A belief or suspicion was capable of being reasonable even though founded on a mistake of law.

- The officer in question need not be convinced that the information in his/her possession was sufficient to commit for trial or convict, or to establish a prima facie case ${ }^{28}$ for conviction before exercising his or her discretion to arrest. ${ }^{29}$

HCA No. 2524 of 1997; and Mungaroo v Attorney General of Trinidad and Tobago HCA Nos. S-1130 and 1131 of 1998.

20 In Morgan v Attorney General of Trinidad and Tobago supra, Kokaram J, adopting per Mendonca J, (now JA) in Barco v Attorney General of Trinidad and Tobago HCA 1388 of 1989, summarised the test for reasonable and probable cause as follows: (a) Did the officer honestly have the requisite suspicion or belief? (b) Did the officer when exercising the power honestly believe in the existence of the "objective" circumstances which he now relies on as the basis for that suspicion or belief? (c) Was his belief in the existence of these circumstances based on reasonable grounds? (d) Did these circumstances constitute reasonable grounds for the requisite suspicion or belief?

21 Morgan $v$ Attorney General of Trinidad and Tobago supra par 17. See also Juman $v$ Attorney General of Trinidad and Tobago CA 22 of 2009.

22 Okpaluba 201316 Potch ER 248-249.

23 Okpaluba "Reasonable Suspicion and Conduct of the Police Officer in Arrest Without Warrant: Are the Demands of the Bill of Rights a Fifth Jurisdiction Fact?" 2014 27(3) SACJ 325.

24 Duncan $v$ Minister of Law and Order 1986 (2) SA 805 (A) 814D-E; Minister of Law and Order v Hurley 1986 (3) SA 568 (A) 579F-G; and Minister of Law and Order v Pavlicevic 1989 (3) SA 679 (A) 684G.

$25 \quad R$ v Storrey (1990) 1 SCR 241 250-251.

26 Chartier v Quebec (Attorney General) (1979) 2 SCR 474 (SCC); and R v Golub (1997) 34 OR (3d) 743 (ONCA) 749.

27 Per Gleeson CJ, Gummow, Hayne and Heydon JJ, Ruddock v Taylor (2005) 222 CLR 612 (HCA) par 40.

28 Attorney General v Hewitt (2000) 2 NZLR 110 (HC); Police v Anderson (1972) NZLR 233, Duffy v Attorney General (1985) CRNZ 599; Hussien v Chong Fook Kam (1970) AC 942 947-948; Caie v Attorney General (2005) NZAR 703 (HC) par 85; and Niao v Attorney General High Court, Rotorua CP 22/96, 11 June 1998.

29 PHE v Ottawa-Carleton (Region) Police Service (2003) OJ No 3512 (SCJ) par 54. 


\section{Information available at the time of arrest and the prosecution}

The requirement that there must be sufficient information at the time of arrest also applies at the time the prosecutor decides to prosecute, although, in any given case, the quality of the information may differ. While, at the time of arrest, what is required is reasonable suspicion that an offence has been or was about to be committed. The information leading to a decision to prosecute need not lead to conviction, but it must be sufficient enough to enable the officer to place a matter before court. The point was made in Clyne $v$ State of $N S W^{30}$ that the information available to the police at the time of arrest disposes of any argument as to absence of a reasonable ground to arrest, whereas the information available at the time the plaintiff was charged, would make the inference that the prosecuting detective did not have an honest belief that the evidence warranted setting the criminal justice system in motion, was simply untenable. The fact that the police were prompted to lay the charge at the commencement of the plaintiff's civil proceedings cannot lead to a contrary conclusion.

\section{Where the arresting and prosecuting officers operated on false information}

The recent Supreme Court of Appeal case of Minister of Safety and Security $v$ Tyokwana ${ }^{31}$ presents an interesting scenario in the sense that the case of the arresting police officer and that of the officer investigating the alleged theft of the arresting officer's official firearm, were riddled with falsehoods at every stage. The arresting officer (Kani) was aware at all material times that the accused and the two witnesses who were with him at the time the offence was allegedly committed, were subjected to assaults in order to obtain their cooperation to provide statements falsely, implicating the respondent. Kani was also aware that any admission or pointing by the respondent was brought about only by the continuous brutal assaults perpetrated on him by the arresting officer and members of the Kenton-onSea police. He was further aware that the information and affidavits initially obtained from the two witnesses blaming the respondent of the theft of the firearm, were extracted from them by forceful means by himself and his fellow police officers. The Court a quo correctly concluded that the appellant had failed to establish that the arresting officer did, at the time of the arrest of the respondent, entertain a suspicion based on reasonable grounds that the respondent had committed a Schedule 1 offence. ${ }^{32}$

Fourie AJA did not only hold that the arrest was unlawful, but that in instigating the prosecution of the respondent, the arresting officer was fully aware of the absence of any credible evidence linking the respondent to the theft of the firearm. Yet, he submitted a false statement denying any assault

\footnotetext{
(2012) NSWCA 265 par 5, 20-24, 65 and 70.

Supra.

Par 27-28.
} 
and duress on the respondent, while failing to inform the presiding magistrate that the respondent had been subjected to brutal and sustained assault by the police, and that his visible injuries were in consequence of the assault. The fact being that it was he, the arresting officer, who persuaded the respondent to provide a false version as to the origin of his injuries to the magistrate. In these circumstances, the arresting officer was not only aware of the absence of reasonable grounds for the prosecution, but could not have had any honest belief that the respondent had been guilty; nevertheless, he persisted, albeit wrongly, with and actively encouraged the prosecution of the respondent, reckless as to the consequences of his conduct. ${ }^{33}$ Furthermore:

"In the court a quo, Kani conceded that, when Hansie and Bokisa deposed to their later affidavits on 9 October 2007, it was clear that, their initial statements, implicating the respondent, were false. He conceded that they were the only two witnesses who could implicate the respondent in the criminal case against him for theft of the firearm, yet he took no steps to advise the prosecutor that, in the circumstances, there was no point in pursuing the prosecution against the respondent. In view thereof, his instigation of the respondent's prosecution and his perpetuation thereof, was malicious."

The Court then considered whether the arrest and detention were wrongful and unlawful. Since the arrest was made without a warrant, the lawfulness or not of the arrest would depend on whether the arresting officer had reasonable suspicion that the respondent had committed a Schedule 1 offence in terms of section 40(1)(b) of the Criminal Procedure Act 51 of 1977. It has already been stated that the arresting officer was aware of the falsity of the evidence available to him, and that it had been obtained by duress. The investigating officer was similarly aware that the two witnesses recanted their initial statements, and had laid a charge of assault against the arresting officer, and yet, failed to bring that information to the attention of the prosecutor or the magistrate. These two law enforcement officers recommended that bail be refused the respondent by stating material untruths in the bail information form with the result that both the prosecutor and the magistrate were not given the opportunity to apply their minds to the question whether or not the respondent should be remanded in custody or granted bail. Had the relevant facts been properly brought to the attention of the prosecutor and the magistrate, it would have been inconceivable that the prosecutor would have permitted the prosecution to proceed, or that the magistrate would have refused bail. Accordingly, the prosecution of the respondent and its perpetuation at the instance of the arresting officer was malicious and constituted a wrongful and improper use of the Court process to deprive the respondent of his liberty. ${ }^{35}$

It is a well-established principle of law that the duty of a police officer who has arrested a person for the purpose of having him or her prosecuted, is to give a fair and honest statement of the relevant facts to the prosecutor,

\footnotetext{
Par 29.

Par 30.

Par 39.
} 
leaving it to the latter to decide whether or not to prosecute. ${ }^{36}$ The Constitutional Court had held in Carmichele $v$ Minister of Safety and Security $^{37}$ that the police had a clear duty to bring to the attention of the prosecutor any factors known to them to be relevant to the exercise by the magistrate of his or her discretion to admit a detainee to bail. For instance, in Tyokwana, both the arresting officer and the investigating officer failed dismally to give a fair and honest statement of the relevant facts to the prosecutor, and to bring all the relevant circumstances to the attention of the magistrate, whereas their distortions and falsehoods secured the continued incarceration without bail from the date of arrest on 2 October 2007 until his acquittal and release on 20 July $2009 .{ }^{38}$ Fourie AJA was satisfied that the respondent had successfully established that the circumstances in which the police officers instigated and persisted with the prosecution, amounted to an unjustifiable breach of the respondent's right to his liberty as guaranteed in section 12(1)(a) of the 1996 Constitution, so as to entitle him to delictual damages for the full period of the respondent's detention. ${ }^{39}$

\section{Was there a reasonable suspicion? The test in English} law 
Wednesbury principles, as they are usually referred to, are applicable to determining the lawfulness of the exercise of the statutory discretion of a constable under section 2(4) of the Criminal Justice Act 1967, not only in proceedings for judicial review but also for the purpose of founding a cause of action at common law for damages for that species of trespass to the person known as false imprisonment, for which the action in the instant case was brought."

The lesson derived from the judgment in Holgate-Mohammed is that the Wednesbury unreasonableness does not only apply when an officer decides to arrest, but also when he decides to detain the suspect. Although the police officer might have had reasonable grounds to suspect that the plaintiff had committed an offence, the wrongful exercise of the discretion inherent in the statutory language in either case may render either the arrest or detention, or both unlawful. When Napier CJ, Bright and Mitchell JJ of the Supreme Court of South Australia addressed similar issues in Drymalik $v$ Feldman, ${ }^{44}$ they observed:

"In our view, the appellants, when they arrested the respondent, honestly believed, on reasonable grounds, that he had committed an offence. However, that is not an end of the matter. The power, which s 75 of the Police Offences Act 1953-1961 entrusts to every member of the Police Force, is admittedly very wide indeed, but that, as it seems to us, imports a power that has to be exercised within the limits, and for the purposes, contemplated by the enactment. It seems to us that it is incumbent on this court to insist upon this view of the enactment. So that, even if the arrest is effected ostensibly in execution of the statutory power and within its letter, it must nevertheless be held not to come within the power, unless it is effected in good faith, and for the purposes contemplated by the enactment."

It was held in that case that the appellants were rightly adjudged liable for the tort of false imprisonment, but the court was not prepared to do so, having had regard to the basis upon which the finding had proceeded. There was no doubt that the appellants had reasonable grounds for suspecting that the plaintiff committed the offence for which the officer purported to arrest him. If only the arresting officer had taken the plaintiff before the justice without unnecessary delay, there would have been no basis for the plaintiff's complaint. However, if the arrest was to afford an opportunity for questioning, then the arrest was unlawful, and, if the detention was effected whilst the plaintiff was being questioned, it was also unlawful.

How did the Court approach the matter of determining the lawfulness of the arrest in Commissioner of Police for the Metropolis $v$ Copeland, ${ }^{46}$ where the arresting officer did not witness the events where it was alleged that the appellant punched a police constable in the face, but had relied on information given to her by the constable? Fortunately, a three-way requirement for that purpose was formulated by Auld LJ in Al-Fayed $v$ Commissioner of Police for the Metropolis, ${ }^{47}$ and founded on the Court of

43 Per Lord Diplock, Holgate-Mohammed v Duke supra 443.

44 [1966] SASR 227.

45 Drymalik v Feldman supra 231-235 citing Maxwell on the Interpretation of Statutes 9ed (1946) 129; and Stockton \& Darlington Railway Co v Brown (1860) 9 HLC 246 256, 11 ER 724728

46 Supra.

47 [2004] EWCA Civ. 1579 (CA). 
Appeal's earlier propositions in Castorina $v$ Chief Constable of Surrey. ${ }^{48}$ According to the judgment in Castorina, the three questions which must be posed are: (a) did the arresting officer suspect that the person was guilty of the offence? The answer to this question depends entirely on the findings of fact of the officer's state of mind; (b) assuming the officer had the necessary suspicion, was there reasonable cause for that suspicion? This is a purely objective requirement to be determined by the judge, if necessary on facts found by a jury; and (c) if the answer to the previous two questions is in the affirmative, then the officer has a discretion which entitled him to make an arrest, and in relation to that discretion the question arises as to whether it has been exercised in accordance with the principles of reasonableness, laid down in Wednesbury. ${ }^{49}$ Following the relevant proposition based on the judicial authorities, Auld LJ proposed in Al-Fayed that: (a) in determining all Castorina questions, the state of mind is that of the arresting officer, subjective as to the first question, the fact of his suspicion, and objective as to the second and third questions, whether he had had reasonable grounds for it, and whether he exercised his discretionary power of arrest, in Wednesbury reasonably; (b) it is for the police to establish the first two Castorina requirements, namely, that an arresting officer suspected that the claimant had committed an arrestable offence, and that he had reasonable grounds for his submission; and (c) if the police established those requirements, the arrest is lawful unless the claimant can establish on Wednesbury principles that the arresting officer's exercise, or non-exercise of his power to arrest, was unreasonable.

In applying the above principles to the facts of Copeland, Moses LJ held that the case did not concern the state of mind of the arresting officer, which was entirely influenced by and dependent on what another officer had told her. Thus, if that officer deliberately lied, then the arrest which was attributable to the allegations and nothing else from another officer, was unlawful, and, there being no issue as to causation, resulted in an imprisonment which was false. ${ }^{51}$ It has been established in Castorina and AlFayed that it is for the police to prove the lawfulness of the arrest, and where that was procured by someone who had deliberately lied and procured the arrest, then it is unlawful. In the ordinary course of events, information from a member of the police service, or an informer or a tip off from a member of the public, even hearsay evidence could constitute reasonable suspicion upon which the arresting officer could act. ${ }^{52}$ The question, as in the present case, however, is whether a defendant to a claim of false imprisonment had himself been the instigator, promoter and active inciter of the action such as the arrest that followed. ${ }^{53}$ The question was not whether the arresting

48 [1996] LGR 241 (CA).

49 Castorina $v$ Chief Constable of Surrey supra 249. See also Al-Fayed $v$ Commissioner of Police for the Metropolis supra par 42.

50 Al-Fayed $v$ Commissioner of Police for the Metropolis supra par 83.

51 Commissioner of Police for the Metropolis $v$ Copeland supra par 18.

52 Hussien v Chong Fook Kam supra 949; O'Hara v Chief Constable of the RUC [1997] AC 286 293C; and Durrant v Chief Constable [2014] EWCA 2922 (QB) par 19.

53 Commissioner of Police for the Metropolis $v$ Copeland supra par 19; and per Lord Bingham MR, Davidson v Chief Constable of North Wales [1984] 2 All ER 597 (CA) 602d and $604 h$. 
officers had acted innocently, but whether the arrest was unlawful by reason of the conduct of the informant in procuring or directly encouraging that arrest by false evidence. The Commissioner could not justify the lawfulness of the arrest and the detention without showing that the constable who requested the arrest of the complainant acted in good faith, and that the arresting officer acted on reasonable grounds and not on the basis of false evidence deliberately intended to procure the arrest of the complainant. ${ }^{54}$

\section{Recent South African case law}

The plaintiff in Woji $v$ Minister of Police ${ }^{55}$ alleged that his arrest and detention by the defendant's employees were unlawful and his prosecution malicious. The first issue the SCA had to determine was whether in arresting the plaintiff, the arresting officer entertained a reasonable suspicion that $\mathrm{W}$ had committed a Schedule 1 offence: robbery. In order to decide the issue, the information available to the officer who arrested $W$ must be examined from an objective standpoint so as to ascertain whether the suspicion he harboured on the accused person's involvement in the robbery was reasonable. The only direct evidence available to the investigating officer regarding the identity of the robbers was a video footage. When the investigating Inspector viewed the footage he recognised the identity of two of the robbers. The face of the third was familiar, but the fourth robber whom he subsequently suspected was $\mathrm{W}$, was unknown to him. Although the Inspector satisfied himself about the person in the footage being the fourth robber, it was quite clear that the facial features of the fourth robber were not clearly seen. However, when all the information available to the Inspector was put together, the Court held that it cumulatively resulted in the Inspector's suspicion being adjudged as objectively reasonable, hence the Minister had discharged the onus of justifying the arrest of W. Such information included: (a) that his name was Vig; (b) that he came from Brighton and had a gold tooth as described by one of the coaccused; and (c) the extremely suspicious circumstances under which he was discovered, together with the broadly similar bodily appearance to the fourth suspect in the video possessed by $\mathrm{W} .{ }^{56}$ Here, unlike in the case of Tyokwana, there was no evidence of twisted facts or brutally obtaining evidence through bodily assaults.

In his claim for unlawful detention, $\mathrm{W}$ had argued that in refusing to grant bail, the magistrate acted upon information supplied by the Inspector. Thus, the Inspector owed a duty to $\mathrm{W}$ to properly investigate the crime, and bring to the attention of the prosecutor and the magistrate at the bail hearing, information which was relevant to the exercise by the magistrate of his discretion. The Inspector had failed to discharge that duty which resulted in the magistrate ordering W's continued detention. The Minister admitted that the Inspector had such legal duty, but denied that he had failed to discharge it. ${ }^{57}$ The argument was that the Inspector failed in the duty which the

54 Commissioner of Police for the Metropolis $v$ Copeland supra par 19-21. See also per Toulson LJ, R (M) v Hackney LBC [2011] 1 WLR 2873 par 36.

2015 (1) SACR 409 (SCA).

56 Woji v Minister of Police supra par 17-18.

57 Par 29. 
Constitution imposed on the State (on whose behalf he acted) not to perform his duties in such a manner as to infringe the right to life, human dignity and security of the person. ${ }^{58}$ In effect, the Inspector had a public duty not to violate W's right to freedom, either by opposing his application for bail, or by placing all relevant and readily available facts before the magistrate. A breach of this public duty gives rise to a breach of the arrested person's right not to be unlawfully detained, which may be compensated by an award of damages. There can be no reason to depart from the general norm of accountability that the State is liable for the failure to perform duties imposed upon it by the Constitution, unless there is a compelling reason to deviate from the norm. W was no doubt entitled to have his right to freedom protected by the State. Accordingly, the Inspector's omission to perform his public duty was wrongful according to private law. ${ }^{59}$

Swain JA held that, as $\mathrm{W}$ was not clearly depicted on the video, the Inspector should not have opposed his application for bail, or should at least have told the magistrate that he was not evidently portrayed on the video. Should a reasonable officer possessing the information of the Inspector have opposed bail? Should such an officer not have foreseen the reasonable possibility that his evidence would lead to refusal of bail? The magistrate ascertained from the Inspector what he had seen in the video, and it was on the basis of the Inspector's assurance that bail was refused. ${ }^{60}$ It was then held that, as the detention of $\mathrm{W}$ was the result of the order granted by the magistrate, in order to determine whether the conduct of the Inspector was a sine qua non, and therefore the factual cause of W's detention. This had to be determined on "what the relevant magistrate on the probabilities would have done", had the application for bail not been opposed, or whether the Inspector revealed that $\mathrm{W}$ was not visibly shown on the video. ${ }^{61}$ Because the video was the only evidence ostensibly linking $W$ to the crime, the magistrate more probably than not would have released him on bail. It is also clear that the Inspector's wrongful conduct was sufficiently closely connected to the loss for liability to follow, hence it also ${ }^{62}$ constituted the legal cause of that loss. The court a quo therefore erred in dismissing the appellant's claim for unlawful detention. ${ }^{63}$ The question whether the facts of this case would also support a claim for malicious prosecution is discussed below in respect of whether negligence could substitute for malice or improper purpose.

The information available to the officer in Minister of Safety and Security $v$ Linda ${ }^{64}$ was that of a woman shot at the scene of the murder and attempted murder. On the basis of this information the investigating officer arrested and charged the respondent. The Full Court of the Pretoria Division found it difficult to understand how the trial Court could conclude that the suspicion

\footnotetext{
Carmichele v Minister of Safety and Security 2001 supra par 44.

Woji v Minister of Police supra par 28; applying the test enunciated in Carmichele v Minister of Safety and Security 2004 (3) SA 305 par 34-38 and 43.

Woji v Minister of Police supra par 30-31.

61 Carmichele $v$ Minister of Safety and Security 2004 supra par 60.

62 Par 71

63 Woji v Minister of Police supra par 32.

642014 (2) SACR 464 (GP) par 38.
} 
arising from those facts was not sufficiently reasonable and that the arrest of the respondent was unlawful in this respect. Any reasonable police officer faced with the statements obtained by the investigating officer in this case would have been derelict in his duties had he not effected an arrest. The trial court accordingly erred in finding that there were no reasonable grounds for the suspicion and that the arrest was unlawful. The appeal was upheld on the claim for unlawful arrest.

\section{Onus of proof on reasonable and probable cause}

There are three points emanating from the English case law that need to be stated from the onset. To begin with, the onus is on the claimant to prove the absence of reasonable and probable cause in order to adduce evidence of "a lack of honest belief in the guilt of the accused". ${ }^{65}$ The next is that the absence of reasonable and probable cause must be established separately, as in the case of each element of malicious prosecution. Moreover, want of reasonable and probable cause can never be inferred from malice since:

- "From the most express malice, the want of probable cause cannot be implied. A man, from malicious motives, may take up a prosecution for real guilt, or he may, from circumstances which he really believes, proceed upon apparent guilt: and in neither case is he liable to this kind of action." $"$.

- "The importance of observing this rule cannot be exaggerated. It behoves the judge to be doubly careful not to leave the question of honest belief to the jury unless there is affirmative evidence of the want of it." ${ }^{67}$ Thus, emphasising that want of reasonable and probable cause can never be inferred from malice, Sharp held in Qema v News Group Newspapers $L t d^{68}$ that there is simply no authority for the proposition that the prosecutor's role must be objectively reasonable.

- Just as it has been shown that it is not necessary for the plaintiff to prove his or her innocence where a nolle prosequi has been entered, so, too, the focus of the defendant on the "guilt" of the claimant is misplaced because ultimate "guilt" in legal terms of a potential claimant in a malicious prosecution claim, or his/her moral unworthiness, if truly guilty, is an issue which is capable of being met in the former case by the requirement that a prosecution must be terminated in a claimant's favour before an action for malicious prosecution can lie, and in the latter, by a defence of illegality (ex turpi causa).

Certainly, the tort is not designed to protect the guilty, but to provide compensation to innocent persons who are prosecuted both maliciously and groundlessly, and there is support in the case law for this proposition. ${ }^{69}$ The

65 Herniman v Smith [1938] AC 305 316; Glinski v Mclver [1962] AC 726 (HL) 744; and Qema v News Group Newspapers Ltd [2012] EWHC 1146 (QB) par 57.

66 Johnson v Sutton (1786) 1 Term Reports 510545.

67 Per Viscount Simonds, Glinski v Mclver supra 744; and Qema v News Group Newspapers Ltd (2012) EWHC 1146 (QB) par 58.

68 Supra par 94

69 Qema v News Group Newspapers Ltd supra par 86-89; and Glinski v Mclver supra 772 and 776. 
point, therefore, is that a person ought not to recover damages for malicious prosecution in circumstances where he or she had committed the criminal acts in question with the requisite intent because in those circumstances there is reasonable and probable cause for his prosecution. At the very least, it might be said that the truth of the charge could have a potentially significant effect on the issue of damage, even if a favourable verdict were to be returned in a malicious prosecution claim. ${ }^{70}$

By far the most extensive analysis of the onus of proof of the element of reasonable and probable cause in a claim for malicious prosecution, and the full impact of the decision of the High Court of Australia in $A v$ New South Wales were brought home by the judgment of the New South Wales Court of Appeal in State of NSW v Quirk. ${ }^{71}$ After a lengthy analysis of the primary judge's findings of facts and their application to the law, Tobias AJA proceeded to lay down at least thirteen legal principles, ${ }^{72}$ perching in instances on the High Court judgment in $A v$ New South Wales. These thirteen principles provides one with literally all that one needs to know with regard to the operation and application of the reasonable and probable cause requirement in the law of malicious prosecution. First, the plaintiff is required to prove two distinct elements, the positive being malice, while the negative is the absence of reasonable and probable cause. Each has a separate role to play in determining liability for malicious prosecution. ${ }^{73}$ Second, although a conclusion about malice does not render it irrelevant (as proof of particular facts may provide evidence of both elements), the inquiries about what the prosecutor did make, and should have made, regarding the material available when deciding whether to initiate or maintain a prosecution. If the prosecution fails, an action for malicious prosecution will not lie where the material before the prosecutor at the time of initiating, or maintaining the charge, both persuaded the prosecutor that laying a charge was proper, and would have been objectively assessed as warranting the laying of a charge. This would be so notwithstanding a finding of malice. ${ }^{74}$ Third, the inquiry about reasonable and probable cause has two aspects: (a) what the prosecutor made of the material available to him/her; and (b) what the prosecutor should have made of it.

While the first is a subjective test, the second is an objective one. ${ }^{75}$ Fourth, the determination of whether there is an absence of reasonable and probable cause must be made at the time the prosecution commenced, and attention is necessarily directed to what material the prosecutor had available for consideration when deciding whether to commence or maintain the prosecution. ${ }^{76}$ Fifth, in an action for malicious prosecution it is important to bear in mind that the plaintiff must establish the negative element absence of reasonable and probable cause, the forensic difficulty of proving

\footnotetext{
Qema v News Group Newspapers Ltd supra par 91.

Supra.

State of NSW $v$ Quirk supra par 70.

State of NSW v Quirk supra par 70(a); and A v New South Wales supra par 54.

State of NSW $v$ Quirk supra par 70(b); and A v New South Wales supra par 54 and 56.

State of NSW $v$ Quirk supra par 70(c); and A v New South Wales supra par 58.

State of NSW v Quirk supra par 70(d); and A v New South Wales supra par 59.
} 
which is well known. However, it is very dependent upon the nature of the forensic circumstances of each case. It is equally important to avoid translating the negative question - whether the defendant/prosecutor acted without reasonable and probable cause - into the different question - what will constitute - reasonable and probable cause to initiate criminal proceedings.

Sixth, subject to the qualification below, Jordan CJ had said in Mitchell $v$ John Heine and Son $L t d^{78}$ that there were five conditions to be met for a person to have reasonable and probable cause for prosecuting another for an offence. They are as follows:

- The prosecutor must believe that the accused is probably guilty of the offence.

- This belief must be founded upon information in the possession of the prosecutor, pointing to such guilt, and not upon mere imagination or surmise.

- Whether the information consists of things he observed himself or things told to him by others, the prosecutor must believe them to be true.

- This belief must be based upon reasonable grounds.

- The information possessed by the prosecutor, and reasonably believed by him to be true, that would justify a man of ordinary prudence and caution in believing that the accused is probably guilty. ${ }^{79}$

Seventh, in order to succeed on the issue of reasonable and probable cause, the plaintiff must establish "that one or more of the foregoing conditions did not exist" which, according to Jordan CJ he may do by

77 State of NSW v Quirk supra par 70(e); and A v New South Wales supra par 60.

78 (1938) 38 SR (NSW) 466 469; and State of NSW $v$ Quirk supra par 70(f).

79 As Sharp J put it in Qema $v$ News Group Newspapers Ltd supra par 71-75, whatever vocabulary one choses to express it, and whatever one considers the objective or subjective element of reasonable and probable cause to be, the focus is, and always has been, the sufficiency of evidence to support the prosecution of the offence in question, and the defendant's knowledge of and honest belief in that evidence. This is what the cases refer to whether the formulation is for a "proper case to put before the court", or "a proper case to be tried", or "a proper case to lay before the court", or "there is a probable cause to bring the accused to a fair and impartial trial", or "sufficient evidence to justify a prosecution." The question, therefore, is not so far as the subjective element is concerned, whether the prosecutor actually believes in the suspect's guilt, or believes the suspect will probably be convicted, nor is he under a duty to find out whether there is a possible defence. So far as the objective element is concerned, the question is not whether the material is sufficient in law to secure a conviction for, as Eady J, observed in Howarth $v$ The Chief Constable of Gwent Constabulary [2011] EWHC 2836 par 16: "It is necessary to consider whether there is adequate material to place before a jury, rather than predict what the jury will conclude." See also Tempest v Snowden [1952] 1 KB 130 135; Glinski v Mclver supra 758 and 766-767; and Coudrat v Commissioners of Her Majesty's Revenue and Customs [2005] EWCA 616 par 16. The claimant in Qema v News Group Newspapers Ltc had no realistic prospect of establishing absence of reasonable cause in the case. In simple terms, if and when the judge examines what facts the defendant/prosecutor acted upon, it is apparent that the defendant knew from personal observation sufficient facts to prove the criminal charges brought against the defendant, and nothing by way of defence, it would be impossible to conclude that the charges were brought without reasonable and probable cause. There was no doubt that the claimant deliberately supplied illegal drugs to one Mahmood (the prosecutor), and possessed illegal drugs and a forged passport with intent to supply them to Mahmood. 
proving, if he can, that the defendant/prosecutor did not believe his being guilty, or that the belief in his guilt was based on insufficient grounds. ${ }^{80}$ Eight, the five conditions stated by Jordan CJ (above) provide guidance about particular kinds of issue that might arise in those cases where the defendant/prosecutor may be supposed to have personal knowledge of the facts giving rise to the charge, and the plaintiff alleges either that the prosecutor did not believe the accused to be guilty, or that the prosecutor's belief in the accused's guilt was based on insufficient grounds. However, those five conditions should not be understood as completely or exhaustively describing what will constitute reasonable and probable cause. ${ }^{81}$

Ninth, where the plaintiff alleges that the defendant/prosecutor did not have the requisite subjective state of mind when instituting or maintaining a prosecution; that is an allegation about the prosecutor's state of persuasion. The subject matter of the relevant state of persuasion in the mind of the prosecutor is the sufficiency of the material then before him to warrant setting the process of the criminal law in motion. If the facts of the particular case are such that the prosecutor may be supposed to know where the truth lies, the relevant state of mind will necessarily entail a conclusion (a belief of the prosecutor) about guilt. ${ }^{82}$ Tenth, the negative proposition that the plaintiff must establish (that the prosecutor acted without reasonable and probable cause) may be established in either both of two ways: the defendant/prosecutor does not "honestly believe" the case that was instituted or maintained, or the defendant/prosecutor has no sufficient basis for such an honest belief. ${ }^{83}$ Eleventh, in most cases, honesty, or more accurately, the allegation of lack of honesty, will require consideration of what the prosecutor knew, believed or concluded, about some aspect of the material. However, if the prosecutor's knowledge or belief must be considered, honesty will add nothing to the inquiry. ${ }^{84}$ Twelfth, what is required is an examination of the prosecutor's state of persuasion regarding the material considered by him or her. That should not be done in treating the five conditions, stated by Jordan $\mathrm{CJ}$ as a complete or exhaustive catalogue of what will constitute reasonable and probable cause, although they are generally sufficient where the prosecutor is not required to act upon information provided by others in Quirk. However, the focus must be on the absence of one or more of those conditions. ${ }^{85}$ Finally, the objective element of the absence of reasonable and probable cause has been couched in terms of the "ordinary prudent and cautious man placed in the position of the accuser", ${ }^{86}$ or explained with reference to "evidence that persons of reasonably sound judgment would regard as sufficient for launching a prosecution". The resolution of the question will most often depend upon identifying what it is that the plaintiff asserts to be deficient about the

State of NSW v Quirk supra par 70(g); and A v New South Wales supra par 64.

State of NSW $v$ Quirk supra par 70(h); and $A \vee$ New South Wales supra par 66.

State of NSW $v$ Quirk supra par 70(i); and $A$ v New South Wales supra par 71.

State of NSW $v$ Quirk supra par 70(j); and A v New South Wales supra par 77.

State of NSW $v$ Quirk supra par 70(k); and $A v$ New South Wales supra par 78.

State of NSW $v$ Quirk supra par 70(I); and A v New South Wales supra par 81.

Hicks v Faulkner (1881) 8 QBD 167171 per Hawkins J; Herniman v Smith supra 316 per Lord Atkin; and Trevor Williamson v Attorney General of Trinidad and Tobago supra par 14. 
material upon which the defendant acted in instituting or maintaining the prosecution. That is an assertion which may (not must) depend upon evidence, demonstrating that further inquiry could and should have been made. Incidentally, no such assertion was made in the present case. ${ }^{87}$

Applying the foregoing guidelines and principles to the facts of Quirk, the New South Wales Court of Appeal held that the respondent could only succeed in demonstrating on the balance of probabilities that there was absence of reasonable and probable cause, if he could persuade the trial judge to make a finding, accepting his version and rejecting that of the prosecuting police officer. In this he failed. It followed that the onus was not discharged hence the generic finding of the trial judge that the respondent had proved the absence of reasonable and probable cause for instituting the proceedings could not stand. ${ }^{88}$ Taking into account the five conditions stated by Jordan $\mathrm{CJ}$ it is clear that the trial judge did not make findings which would justify the conclusion that the respondent had established, on the balance of probabilities, that one or more of those conditions did not exist. ${ }^{89}$ Since there was no finding as to whether the prosecuting police officer's belief that each of the offences for which the respondent was charged had been supported by sufficient material of which he had personal knowledge to warrant framing the charges, nor was there a finding that the objective standard of sufficiency was not satisfied. It follows that a critical ingredient of the malicious prosecution cause of action was not established, and thus the action fails on that account. ${ }^{90}$ Lastly, as "it was not open to the primary judge to find that the respondent had proved the absence of reasonable and probable cause in respect of each of the four offences with which the respondent was charged, it is unnecessary to deal with the issue of malice." ${ }^{91}$

\section{Privy Council judgment in Williamson}

In Trevor Williamson v Attorney General of Trinidad and Tobago, ${ }^{92}$ the Privy Council reiterated what has been said above, that is, that in order to make out a claim for malicious prosecution, it must be shown, inter alia, that the prosecutor lacked reasonable and probable cause for the prosecution, and that he or she was actuated by malice. These particular elements constitute a significant challenge by way of proof. Their Lordships went further to hold that an allegation that there was no reasonable and probable cause for the launch of the proceedings required the proof of a negative proposition,

\footnotetext{
State of NSW v Quirk supra par 70(m); and A v New South Wales supra par 83 and 86.

Par 144.

Par 145.

Par 146.

91 Par 147. Since State of NSW $v$ Quirk was decided, a number of cases have been handed down in Australia, where the issue of absence of reasonable and probable cause as a vital element of the malicious prosecution cause of action has been raised, and the judgments have followed the principles laid down in A v New South Wales; State of NSW v Quirk and State of NSW v Landini [2010] NSWCA 157. See eg, State of New South Wales v Abed [2014] NSWCA 419; Bailey v Director General, Department of Natural Resources (2015) NSWCA 318 par 12-15; Clavel v Savage [2015] NSWCA 61 par 101-102, 109, 112, 118-119; Beckett v New South Wales [2015] NSWSC 1017 par 576; and Nash v State of New South Wales [2015] NSWDC 144 par 140-142. Supra par 11
}

92 
normally among the most difficult of evidential requirements. In order to satisfy this requirement, the prosecutor must have an honest belief in the guilt of the accused, based upon a full conviction, founded upon reasonable grounds, of the existence of a state of circumstances, which, assuming their being true, would reasonably lead any ordinary prudent and cautious person, placed in the position of the accuser, to conclude that the person charged was probably guilty of the crime imputed. ${ }^{93}$ Their Lordships restated that the honest belief required of the prosecutor is a belief not that the accused is guilty as a matter of certainty, but that there is a proper case to lay before the court. ${ }^{94}$

In light of their finding on the element of malice, their Lordships did not consider the correctness of the finding of the Court of Appeal that the prosecutor did not have reasonable and probable cause to proceed with the charge that was preferred against Mr Williamson because he should have been charged as a secondary participant in a joint enterprise. ${ }^{95}$ On the one hand, the evidence against Mr Williamson, taken in the round and including his cooperation with the police, could be regarded as indicative of his innocence of the charge. On the other hand, his activities, and that of his passenger, were sufficient to arouse the suspicions of the witness who might have thought that taking household goods to the taxi when the owner of the house was absent, might be untoward; or, at least, downright suspicious. If, indeed, Mr Williamson had been complicit in the theft of the goods, he had ready explanation if questioned about it, namely, that he was an innocent taxi driver. However, the rehearsal of that explanation did not establish his innocence. It is what an astute police officer would have expected a person who was in fact guilty to say, although it is, of course, also consistent with innocence. But it does not irrefutably and inevitably lead to that conclusion. One must bear in mind that the person who hired the taxi was not found in the address where Mr Williamson took the police and where, he said, he had left him. In these circumstances, to have continued to harbour suspicions about Mr Williamson, even after he had given his explanation, cannot make the police officer's decision to proceed with the charge unreasonable ${ }^{96}$ Their Lordships agreed with the Court of Appeal that it was right to have concluded that, once it is shown that there was a reasonable and probable cause to prosecute, the fact that the prosecuting officer subsequently laid the "wrong" charge, would not have deprived the prosecuting officer of that reasonable and probable cause. Surely, it is beyond argument that the reasonableness of an officer's suspicion at the time of arrest cannot be undermined by some defect in the charges eventually laid against the suspect. ${ }^{97}$ This ruling is in accord with what Lord Simonds said in Christie $v$ Leachinsky, ${ }^{98}$ to the effect that "it is not an essential condition of lawful arrest that the constable should at the time of arrest formulate any charge at all, much less the charge which may ultimately be found in the indictment."

93 Par 14; per Hawkins J, Hicks v Faulkner supra 171.

94 Per Lord Denning, Glinski v Mclver supra 758.

95 Trevor Williamson v Attorney General of Trinidad and Tobago supra par 15.

96 Par 16.

97 Par 21.

98 [1947] AC 573593. 


\section{Calabro v State of Western Australia}

The plaintiff in $v$ State of Western Australia ${ }^{99}$ brought an action against several defendants, including the State prosecutor and the DPP, for abuse of process and malicious prosecution. Although a notice was filed by the DPP to discontinue all the charges brought against him for "lack of grounds" for a conviction, in order for him to pursue his claim for malicious prosecution, he had to establish the absence of reasonable and probable cause as well as improper motive. But the essential thrust of the materials he filed in Court which were "repetitiously stated", was that he contended that the charges brought against him were "always baseless". This, in effect, was the sole foundation put forward to advance his proposed claims for malicious prosecution against the two officials over their alleged "continuing" or "maintaining" the prosecution against him. ${ }^{100}$ Kenneth Martin could detect nothing upon a thorough scrutiny of all the materials chronicling the events leading to the present action - his arrest, detention, appearances before the District Court and the discontinuation of the charges - to suggest any potential basis for an argument that the third and fourth elements of the tort of malicious prosecution as itemised in $A v$ New South Wales might possibly be maintained against the State prosecutor and the DPP. The appropriate rule of court clearly indicates what can be put in the writ, but the endorsements of claim seen under all of the plaintiff's writ iterations, failed to meet the requirements of Order 6 rule 1(1) of the RSC. The rule refers to the writ being "indorsed with a concise statement of the nature of the claim made, and of the remedy or relief required in the action". The plaintiff's endorsements instead took the character of repetitious narratives. Granting that the plaintiff was unrepresented, and substantial allowances were made to accommodate that shortcoming, the desired extra contention of malicious prosecution against the defendants required "some underlying basis more than a formulaic repletion of the bare elements of the tort and repetitive references to 'baseless' charges." ${ }^{101}$ Even if the charges were discontinued for lack of confidence towards securing conviction of the plaintiff that, of itself, was insufficient indicia that there was not an existence of reasonable and probable cause for a prosecution at the material time of his indictment. Further, the fact that the indicted charges were later dropped was no basis on which to legitimately infer from the fact of dismissal alone that there was no reasonable and probable cause for a prosecution at the time that $\mathrm{Mr}$ Calabro was indicted. ${ }^{102}$ Manifestly in support of this finding is the joint judgment of Gleeson CJ et al in $A v$ New South Wales, where their Lordships addressed a "temporal dimension" to the law of malicious prosecution which calls attention to the state of affairs at the time the prosecution was commenced, or when the prosecutor was alleged to have maintained the prosecution. This also tends to direct attention to the materials available to the prosecutor for consideration whether to commence

\footnotetext{
[2013] WASC 367.

Calabro v State of Western Australia supra par 27.

101 Par 28-29.

102 Par 30-31.
} 
or maintain the prosecution, and not whatever material that might emerge later in the process. ${ }^{103}$

In Calabro, the Court accordingly held that it had not been demonstrated on Mr Calabro's materials that there was any arguable basis to obtain leave to add the State prosecutor and the DPP as extra parties, pursuant to RSC O 18 r 6(2)(b). Likewise, no basis for leave to add additional parties and further causes of action, necessarily associated with proceeding against such extra parties in accordance with RSC O 21 r 1(3)(a) and (b), could be established. As these presenting deficiencies were raised, they appeared to have been insurmountable hence the withdrawal of his leave application. ${ }^{104}$ Similarly, the plaintiff's alternate cause of action on the basis of collateral abuse of process the presentation of which was equally conceptually deficient, was thrown out because it failed to show that the party who instituted the proceedings did so for the purpose, or to effect an object beyond that which the legal process offers. ${ }^{105}$ There was, therefore, nothing in any of the materials presented by Mr Calabro which indicated that he had any prospect of meeting the requirements to enable him proceed with either the malicious prosecution claim or the abuse-of-process cause of action. There was nothing to indicate an improper purpose, or an extraneous object on the part of the State prosecutor and/or the DPP, other than bringing the charges on which the plaintiff was indicted. ${ }^{106}$

\section{Minister of Safety and Security NO v Schubach ${ }^{107}$}

After recounting the four elements of malicious prosecution in Schubach, ${ }^{108}$ Zondi proceeded to deal with the submissions of the DPP, that the court below was wrong to have found that the DPP's decision to prosecute the respondent on some charges was malicious, but not malicious on others. It was further argued that the decision to prosecute constituted a single intent and a single act; its reasonableness had to be evaluated in its entirety; and it was wrong to conduct such an evaluation separately since it is inconceivable that the prosecutor would have a malicious intent for one set of charges and not for the other. He either has malicious intent (animo injuriandi) or not. ${ }^{109}$ In rejecting the argument, the Justice of Appeal held that the set of charges was discrete, and had to be considered separately in determining the absence of reasonable and probable cause. Considerations pertaining to the one set of charges cannot be transposed onto the other. In other words, the fact that there was a reasonable and probable cause to prosecute on one set of charges, has no effect on the outcome of the enquiry in relation to the

103 A v New South Wales supra par 59. See also per Owen JA, Noye $v$ Robbins [2010] WASCA 83 par 205; and Beazley JA, A v New South Wales (2005) NSWLR 631 par 172.

104 Calabro v State of Western Australia supra par 34.

105 Par 35; Williams v Spautz (1992) 174 CLR 509523

106 Par 35; Williams v Spautz supra 526-527.

107 Supra 216.

108 Minister of Safety and Security NO $v$ Schubach supra par 11. See also Minister of Justice and Constitutional Affairs v Moleko 2009 supra par 8; and Rudolph v Minister of Safety and Security supra par 6.

109 Minister of Safety and Security NO v Schubach supra par 12. 
other set of charges. This is because the question whether reasonable grounds for the prosecution exists, is answered only by reference to the facts of each case. ${ }^{110}$

Having regard to the test enunciated in Beckenstrater $v$ Rottcher and Theusissen, ${ }^{111}$ which contain both the subjective in the sense that there must be both actual belief on the part of the prosecutor, and the objective element to the effect that the belief must be reasonable in the circumstances, Zondi JJA held that it was common cause that there was no probable cause to prosecute on the charges relating to the firearms and ammunition for which he and his wife had licences, because the DPP had given instructions that those charges be withdrawn. The continued prosecution on those charges was malicious. ${ }^{112}$ Bearing in mind that the explosives and the service pistol were found in a police safe, and were used by the police, there could be no basis for the contention that the DPP's decision to prosecute the respondent on those charges was based on reasonable and probable cause. Again, the conclusion of the court below on the respondent's prosecution on those charges could not be faulted. Finally, the inescapable inference to be drawn from the facts of the case is that those responsible for initiating the prosecution against the respondent on the charges in question were aware of what they were doing and foresaw the possibility of their acting wrongfully, but nevertheless acted recklessly regarding the consequences of their conduct. ${ }^{113}$

\section{Biladeau v Ontario}

The decision to initiate or continue with a criminal prosecution is one of the "core elements" of prosecutorial discretion which is beyond the legitimate reach of the court unless a Crown prosecutor stepped out of his or her role as "minister of justice". ${ }^{114}$ Canadian courts have since held the view that as much as the prosecutor's duties should be carried out firmly and fairly, ${ }^{115}$ it does not carry with it a notion of winning or losing, neither is it the Crown's function to persuade a jury to convict other than by reason. ${ }^{116}$ Thus, "rhetorical techniques that distort the fact-finding process", and misleading and highly prejudicial statements, have no place in a criminal prosecution. ${ }^{11}$ Although some of these types of forbidden ethical conduct on the part of a Crown prosecutor were identified in the case of an experienced prosecutor in Biladeau $v$ Ontario, ${ }^{118}$ the two elements of malicious prosecution in contention in the case were: the absence of reasonable and probable cause and malice. For instance, the trial judge's address to the jury in the trial of the appellant did not go down well with Sharpe JA in setting aside the

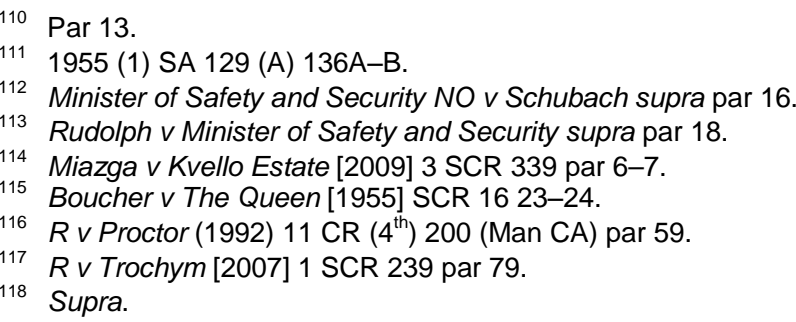


appellant's conviction. ${ }^{119}$ The Justice of Appeal held that the prosecutor's adverse comments on the appellant having elected not to give evidence, and thus not subjected to cross-examination, was an indication that he was guilty of a violation of the appellant's right under the Evidence Act and an infringement of his right to a fair trial.

The appellant had argued that the Crown's offer, and the eventual abandonment of the case, show that the Crown was aware that it had a weak case against him, confirmed by Sharpe JA's comment that the Crown's case "was not overwhelming". These facts clearly indicate that the Crown did not have reasonable and probable cause to commence or continue the prosecution. In accepting the appellant's argument, LaForme JA held that the facts pleaded, had they been accepted as true, and had the claim been read as generously as possible, with the inadequacies being accommodated, that these facts would have been sufficient to survive the Crown's rule 21 motion in connection with the absence of reasonable and probable cause. ${ }^{120}$ On the issue of malice, the Justice of Appeal upheld the necessary inference from the appellant's pleadings that the trial Crown may have been motivated by the improper purpose of getting a conviction at all costs, or that he might have been attempting to get a mistrial. In any event, LaForme held that there was evidence that the trial Crown employed misleading and highly prejudicial statements as well as rhetorical techniques that distorted the fact-finding process. A trial Crown, a minister of justice, who relies on such dubious strategies, may be motivated by an improper purpose such as using these strategies to persuade a jury to convict otherwise than by reason. ${ }^{121}$

\section{MALICE}

Emphasising that malice must be established alongside reasonable and probable cause, their Lordships of the Privy Council accepted in Williamson, ${ }^{122}$ that the Australian High Court judgment in $A v$ New South Wales $^{123}$ has provided "a good working definition" of what was required for proof of malice in the criminal law context. The High Court had said in that case that: "what is clear is that, to constitute malice, the dominant purpose of the prosecutor must be a purpose other than the proper invocation of the criminal law - an 'illegitimate or oblique motive'. That improper purpose must be the sole or dominant purpose actuating the prosecutor." Their Lordships held that an improper and wrongful motive lies at the heart of an action for malicious prosecution; it is the "driving force" behind the prosecution. In effect, it has to be shown that the prosecutor's motives are for a purpose other than bringing a person to justice. ${ }^{124}$

$119 R$ v Biladeau (2008) 93 OR (3d) 239 par 31 and 35.

120 Biladeau $v$ Ontario supra par 29-30.

121 Par 35-36.

122 Trevor Williamson v Attorney General of Trinidad and Tobago supra par 11.

123 Supra par 91.

124 Crawford Adjusters v Sagicor General Insurance (Cayman) Ltd supra par 101; Gregory v Portsmouth City Council [2000] 1 AC 419 (HL); Proulx v Quebec (Attorney General) [2001] 
Although malice can be inferred from the absence of a reasonable and probable cause; ${ }^{125}$ in the final analysis, however, a finding of malice is always dependent on the facts of each case. It is imperative for the tribunal to make a finding according to its assessment of unshakably factual evidence. $^{126}$ So, given the statement above, the conclusion on the Williamson's case ${ }^{127}$ bears directly on the question whether the prosecution can be inferred to be malicious. Where there is absolutely no basis for suspicion, especially where that is accompanied by an apparent reluctance to proceed with the charge, one might draw such an inference. But that was not remotely the position in Williamson. Although it was reprehensible that the prosecuting officer was absent in court on a number of occasions the accused came before the magistrate, but that alone was not sufficient to lead to an inference that the intention of the officer was to manipulate the legal system, or to pursue the prosecution for a wholly extraneous and improper motive. ${ }^{128}$ Further, the claim of the prosecuting police officer that he had reasonable and probable cause for laying the charges and prosecuting Mr Williamson, and that he had acted in good faith and without malice all along, was not challenged. It was thus not surprising that the lower courts were not prepared to infer that the prosecuting police officer had acted with malice in the circumstances. Mr Williamson's appeal against the finding that he had not made out a case of malicious prosecution was therefore dismissed. ${ }^{129}$

Similarly, in his judgment in Quirk, Tobias AJA laid down the following principles in respect of malice. Firstly, the plaintiff must establish that the dominant purpose of the prosecutor was a purpose other than the proper invocation of the criminal law - an "illegitimate or oblique motive". That improper purpose must be the sole or dominant purpose actuating the prosecutor. Various examples are given of malice, such as personal animus, ill-will, and spite, a desire to punish the plaintiff or to stop a civil action brought by the plaintiff against the prosecutor. The list is inexhaustive. ${ }^{130}$ Malice can be defined only by the negative proposition: a purpose other than a proper purpose. ${ }^{131}$ Secondly, although proof of malice is often a matter of inference, it is proof that is required, not conjecture or suspicion. It requires evidence from which the Court can infer that the prosecutor wished to pursue some illegitimate or oblique motive other than a proper invocation of the criminal law. ${ }^{132}$ It can be found where a prosecutor decides to secure a

3 SCR 9; Gibbs v Rea [1998] AC 786 797D; and Stevens v Midland Counties Railway Company (1854) 10 Exch 352356.

125 Brown v Hawkes [1891] 2 QB 718723.

126 Trevor Williamson v Attorney General of Trinidad and Tobago supra par 13.

127 Par 16.

128 Par 17.

129 Par 18.

130 Thus, it was held in Imran Khan v Attorney General of Trinidad and Tobago supra par 71-72, where the claimant who alleged that the prosecuting police officer fabricated charges against the claimant had, indeed, no proper motive for the prosecution. His motive was not to secure the ends of justice but to penalise the claimant directly on his own. To that extent he acted maliciously in initiating the prosecution.

${ }^{131}$ A v New South Wales supra par 91-92.

132 Par 93. 
conviction at all costs, and therefore conducts the case "with tunnel vision". ${ }^{133}$

\section{Improper purpose}

In Nelles $v$ Ontario, ${ }^{134}$ Lamer $\mathrm{J}$ had equated malice with improper purpose of which the British Columbia Court of Appeal has held is tantamount to fraud regarding the process of criminal justice. ${ }^{135}$ There was absence of reasonable and probable cause in Clifford $v$ Chief Constable of the Hertfordshire Constabulary, ${ }^{136}$ where a malicious prosecution claim was brought by a claimant who had been charged with child pornography offences of which he was acquitted because no evidence was offered against him. Mackay $\mathrm{J}$ held that the prosecutor did not have a case which was sufficient, either to lead to a conclusion that there would probably be a conviction, or even that it was a proper charge to put before a court. Even after the County Court Judge had questioned the admissibility and relevance of the evidence tendered, the investigating officer had no further answer. In these circumstances, Mackay $\mathrm{J}$ held that the investigating officer had no reasonable and probable cause, either on the basis of his own honest belief, or judged objectively by the standards of a reasonable prosecutor in his position, to charge the claimant with the possession offences. Malice can be inferred from the absence of reasonable and probable cause if evidence warrants it. Malice, in the present context, covers not only ill will but also improper motive for the prosecution. The plaintiff was all along critical of the conduct of the investigation by the investigating officer. Not only did the investigating officer not have honest belief in the possession charges when he caused them to be brought against the claimant, but he also did so for an improper reason, namely, which he gave to bolster the case on the incitement charge, and to protect his own position, the lies he told along the way, all fortified the Court's finding of improper motive.

\section{Targeted malice: The case of aggregated acts and intentions of individual officers}

The defendant in Chapel Road Pty Ltd v ASIC (No 10), ${ }^{137}$ Australian Securities and Investment Commission (ASIC), had revoked the plaintiff's security dealer's licence after a decision was made by its delegate, $\mathrm{Mr}$ Reynolds. The plaintiff successfully challenged that decision at the Administrative Appeals Tribunal, and the revocation was set aside. The matter was remitted to ASIC with a direction that the plaintiff's licence be reinstated, subject to appropriate conditions, with a view to ensuring effective compliance with the conditions of its licence. That success

133 Per LaForme JA, Ferri v Root (2007) 279 DLR $\left(4^{\text {th }}\right)($ ONCA) par 87.

134 [1989] 2 SCR 170 par 639.

135 Strauss $v$ Jarvis 2007 BCCA 605 (CanLII) par 16. See also Whitty $v$ Wells 2014 ONSC 4920 par 45; NB Real Estate Association v Estabrooks 2014 NBCA 48 par 62-71; and Samaroo v Canada Revenue Agency 2013 BCSC 482 par 19.

136 [2011] EWHC 815 (QB) par 42-44

137 (2014) 307 ALR 428 (NSWSC). 
notwithstanding, the plaintiff did not resume its former business. In this action for misfeasance in public office and malicious prosecution, the plaintiff alleged that its licence was revoked for improper reasons, ASIC having intended thereby to cause it harm. The claim was struck out by Associate Judge Harrison on the ground that a company could not maintain a claim for malicious prosecution, whereas ASIC had acted in accordance with the power vested in it by the law. ${ }^{138}$ Howie, upheld the appeal in part and held that malicious prosecution was generally confined to criminal proceedings and some specific civil proceedings, but not to civil proceedings outside the specific proceedings. ${ }^{139}$ Before Schmidt J the plaintiff, Chapel Road, contended that, while ASIC was entitled to investigate its operations, but it had wrongly targeted it for punishment for some time, and the eventual result was that its licence was wrongly revoked as the result of conduct wrongly pursued by ASIC officers, until the decision revoking the licence was made by Mr Reynolds. It argued that that conduct was malicious, pursued with the intention of damaging the plaintiff, by loss of its licence. ${ }^{140}$ In other words, the decision of the delegate to revoke the plaintiff's licence was an act and decision performed in bad faith, for ulterior motive, and performed with the intention of causing harm to the plaintiff. Therefore it was done maliciously, and was an act performed and decision taken by a public officer (ASIC) in the purported discharge of public duties which did in fact cause loss to the plaintiff. ${ }^{141}$ Responding to the elements of the tort which were outlined in Northern Territory $v$ Mengel,${ }^{142}$ where Deane $\mathrm{J}$ said that they are: (a) an invalid or unauthorised act; (b) done maliciously; (c) by a public officer; (d) in the purported discharge of his or her public duties; (e) which causes loss or harm to the plaintiff, Chapel Road contended that the tort was not confined to these strict parameters, and that in the case of targeted malice as it has alleged, it may not be necessary to establish that the act relied on was invalid or unauthorised. ${ }^{143}$ In any event, it continued, if an act within the defendant's power was done for the improper motive of doing the target harm, then it was done in bad faith and was exercised unlawfully. ${ }^{144}$ The issue turned on whether this tort, claimed to be the result of targeted malice, could be established by aggregating the acts of various officers, as Chapel Road sought to do.

Schmidt $\mathrm{J}$ held ${ }^{145}$ that it was apparent from the authorities that the limits of the tort of misfeasance in public office were not yet settled. ${ }^{146}$ There was, however, no question that conduct which constituted an abuse of power might be either a deliberate act or a deliberate omission, ${ }^{147}$ but not all acts of a public officer involve the exercise of a public power or duty. ${ }^{148}$ Brennan $\mathrm{J}$ in

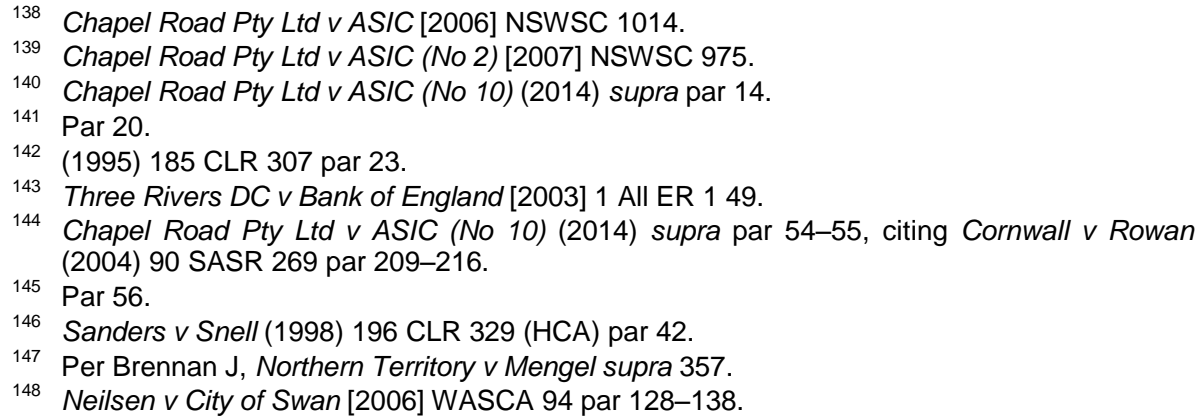


Mengel described the tort as involving "a purported exercise of some power or authority by a public officer otherwise than in an honest attempt to perform functions of his or her office whereby loss is caused to a plaintiff. ${ }^{149}$ A denial of procedural fairness is an act which can constitute the tort, but it is not every such denial which will be sufficient. ${ }^{150}$ While a corporate entity such as ASIC can act only through its officers or delegates, when targeted malice was alleged, given its nature, misfeasance in public office, concerned as it were with the acts and intentions of individuals, could not be established simply by aggregating the acts of various public officers, or establishing a course of conduct, which was claimed was improper or tainted in some way. Such a case must be pleaded, including regarding the knowledge that the impugned conduct would be likely to cause the particular damage, attributed to the misfeasance, which is claimed to be linked to the conduct. ${ }^{151}$

That ASIC or its officers were wrongly, or unlawfully motivated to harm Chapel Road when the decision to pursue a second period of surveillance was made, was not established. At that time, it was considering whether additional licence conditions, rather than enforceable undertakings, were the appropriate regulatory response. Licence revocation was not considered as a possibility before Mr Reynolds, but ASIC's delegate came to consider what the second surveillance had uncovered. The court held that the evidence did not permit the conclusion that any officer involved in the decision to pursue a second period of surveillance acted maliciously. ${ }^{152}$ The available evidence clearly demonstrated that the decision to issue the notice of hearing was not made unlawfully, for a malicious purpose, namely to do Chapel Road harm. The officers in question were not holding an honest belief that the notice of hearing should be issued, but rather seeking to harm it. At that point no decision had been made that Chapel Road's licence should be revoked, although all four of those officers plainly considered that licence conditions remained an option, Mr Reynolds, however, was of the view that the matters raised were sufficiently serious that they may warrant licence revocation. The evidence lawfully established that there was a reasonable basis for those views. ${ }^{153}$ That Mr Reynolds's decision to revoke Chapel Road's licence was made unlawfully, for a malicious purpose, namely to do Chapel Road harm, as it alleged, was not established. On the contrary, his decision more than explained his reasons for reaching the conclusion that the licence should be revoked. The evidence did not provide any foundation for the conclusion that he did not hold those views or that they had no proper basis. To the contrary, the material before him, and the case advanced by Chapel Road, clearly explained the decision which Mr Reynolds reached. The fact that the decision was overturned by the Appeal Tribunal is no reason why a different conclusion could now be reached. ${ }^{154}$

149 Per Brennan J, Northern Territory $v$ Mengel supra 357.

150 Sanders $v$ Snell supra par 38-45.

151 Chapel Road Pty Ltd v ASIC (No 10) (2014) supra par 77. See also Leinenga v Logan City Council [2006] QSC 294 par 66; and Moder v Commonwealth [2012] QCA 92 par 73.

152 Chapel Road Pty Ltd v ASIC (No 10) (2014) supra par 484-485.

153 Par 502-503.

154 Par 504-505. 


\section{Can negligence substitute for malice?}

If the facts of Woji $v$ Minister of Police ${ }^{155}$ establish wrongful and unlawful arrest and detention, would those same facts also lead to a finding of liability for malicious prosecution? In an earlier discussion of that case, it was noted that the SCA held the Minister liable in damages in respect of W's unlawful detention. However, malicious prosecution requires not only that there was prosecution which ended in favour of the plaintiff, but there would have been malice and absence of reasonable and probable cause. ${ }^{156}$ In order to prove the element of malice in this case, it must be ascertained whether the Inspector did anything more than one would expect of a police officer in circumstances which is to give a fair and honest statement of the facts to the prosecutor, leaving it to the latter to decide whether or not to prosecute. ${ }^{157}$ The SCA had held in Moleko that negligence or gross negligence short of dolus eventualis ${ }^{158}$ would not suffice: the defendant must have been aware of the wrongfulness of his or her conduct in initiating or continuing the prosecution, but nevertheless continued to act recklessly regarding the consequences of his or her conduct. ${ }^{159}$ Swain JA held in the present case that when regard is had to all the evidence, including the additional information that the Inspector had pertaining to the identity of the fourth robber, "this engendered a reasonable suspicion in him that this person [in the video] was Mr W. This suspicion clearly coloured his perception of the video material to such a degree that he genuinely believed it depicted $\mathrm{Mr} \mathrm{W}$. In this situation he acted negligently, even grossly negligently." result, the officer gave an honest but unfair statement of facts, implicating $\mathrm{W}$ to the prosecutor and the magistrate. This does not show that the Inspector subjectively foresaw the possibility that the individual in the video was not W, and recklessly continued to assert that he was. W was therefore unable to establish the malice element to support his claim for malicious prosecution and so a claim for malicious arrest similarly failed. ${ }^{161}$

The South African approach is akin to that of the Supreme Court of Canada where it has been held that an action for malicious prosecution must be based on a much higher threshold of deliberate and intentional conduct than recklessness or gross negligence. The intention to cause harm must be present rather than lack of due care, or mere inadvertence to prevent harm. It requires evidence that would reveal a wilful and intentional effort on the part of the Crown to abuse or distort its proper role within the criminal justice system, a deliberate use of the office for ends that are improper and inconsistent with the traditional prosecutorial function. Malicious prosecution

\footnotetext{
2015 (1) SACR 409 (SCA).

Woji v Minister of Police supra par 33.

157 Minister of Justice and Constitutional Affairs v Moleko 2009 supra par 11.

158 This expression of the criminal law has been a source of controversy in recent times: $S V$ Ndlanzi [2014] ZASCA 31; S v Tonkin 2014 (1) SACR 583 (SCA); S v Humphreys 2013 (2) SACR 1 (SCA); and S v Pistorious 2014 JDR 2127 (GP). See also Paizes "Dolus Eventualis Again" 20141 CJR 11; same author, "Dolus Eventualis Revisited" 20131 CJR 5; Hoctor "Recent Cases: General Principles and Specific Offences" 2015 28(1) SACJ 73 par 1.1; and same author, "The Degree of Foresight in Dolus Eventualis" 2013 SACJ 131.

159 Minister of Justice and Constitutional Affairs v Moleko 2009 supra par 64.

160 Woji v Minister of Police supra par 37.
}

161 Par 37. 
must, therefore, be based on more than recklessness or gross negligence. $^{162}$

\section{$4 \quad$ CONCLUSION}

This article set out to investigate the extent to which recent judgments have contributed to the development of the elements of malice and reasonable and probable cause in the law of malicious prosecution in the Commonwealth. Not only that the Australian High Court had provided us with "a good working definition" of what is required to be proved in these two essential requirements for an action for malicious prosecution, ${ }^{163}$ but also, that the New South Wales Court of Appeal in its judgment in State of NSW V Quirk $^{164}$ has gone further to articulate, amplify and expand that "working definition". In the process, it has, in turn, produced a more comprehensive guideline on the burden of proof of malice and reasonable and probable cause. Similarly, the Privy Council has brought clarity to the understanding of these two elements in contemporary Commonwealth jurisprudence. ${ }^{165}$ In similar vein, the recent South African cases of Minister of Safety and Security $v$ Tyokwana, ${ }^{166}$ and Woji $v$ Minister of Police, ${ }^{167}$ as well as the English Court of Appeal in Commissioner of Police for the Metropolis $v$ Copeland ${ }^{168}$ have thrown more light on the persistent problems surrounding the seemingly overlapping of the issues of reasonable suspicion to arrest, and reasonable and probable cause to prosecute. While the English and Canadian cases of Clifford $v$ Chief Constable of the Hertfordshire Constabulary $^{169}$ and Whitty $v$ Wells ${ }^{170}$ deal with improper purpose, the Australian case of Chapel Road Pty Ltd v ASIC (No 10), ${ }^{171}$ concerns the question of aggregated acts and intentions of individual public officers in a situation of targeted malice. In the final analysis, the monumental and developmental rise in the litigation in the modern law of malicious prosecution in the Commonwealth is a manifestation of the extent to which this cause of action has become a veritable avenue through which the State is held accountable by way of the private law of damages for breaches of the individual's personal liberty, human dignity and personality rights in the discharge of law enforcement duties by agents of the State.

\footnotetext{
162 Proulx v Quebec (2001) 206 DLR $\left(4^{\text {th }}\right) 1$ par 35; and Dix v Canada (Attorney General) (2002) 7 Alta LR (4 $\left.{ }^{\text {th }}\right) 205$ (ABQB) par 495.

163 A v New South Wales supra.

164 Supra 216.

165 Trevor Williamson v Attorney General of Trinidad and Tobago supra par 11.

166 Supra.

167 Supra.

168 Supra.

169 Supra par 42-44.

170 Supra.

171 (2014) Supra.
} 